\begin{tabular}{|c|c|c|c|}
\hline UNT B B & AHASA & $\begin{array}{l}\text { Journal of } \\
\text { English Language Teaching } \\
\text { Innovations and Materials }\end{array}$ & \\
\hline $\begin{array}{l}\text { Article received } \\
\text { Article accepted } \\
\text { Published }\end{array}$ & $\begin{array}{l}: 5 \text { th December } 2020 \\
: 5^{\text {th }} \text { October } 2020 \\
: 10^{\text {th }} \text { October } 2020\end{array}$ & - & $\begin{array}{l}\text { Vol. 2(2) } \\
\text { October } \\
2020\end{array}$ \\
\hline
\end{tabular}

\title{
Improving students' interest in learning simple past tense using teams games tournaments
}

\author{
Yusnita Yusnita1, Yuniarti Yuniarti² \\ ${ }^{1}$ Madrasah Tsanawiyah Negeri 2 Pontianak, Indonesia \\ ${ }^{2}$ Early-Childhood Education Study Program, Faculty of Education and Teacher Training, \\ Universitas Muhammadiyah Pontianak, Indonesia \\ yuniarti@unmuhpnk.ac.id
}

DOI: http://dx.doi.org/10.26418/jeltim.v2i2.37832

\begin{abstract}
This study aims to describe the students' interests and perceptions in learning simple past tense by using the TGT (Team Game Tournament) technique. The situation in the teaching-learning process at an Islamic Junior High School in Pontianak has shown that there are still many problems that must be addressed, concerning English grammar. The researcher has encountered several problems such as student's reluctance to participate, lack of interest, motivation, and attention in the classroom. The researcher employed Classroom Action Research as a means to solve the problems. The findings presented information regarding the use of TGT that could serve as a beneficial alternative in teaching grammar, particularly the simple past tense. Furthermore, the information will provide the teacher with useful insights on ways to teach and to motivate their students in the classroom.
\end{abstract}

Keywords: students' interest, simple past tense, teams games tournaments

How to cite this paper: Yusnita, Y., \& Yuniarti, Y. (2020). Improving Students' Interest in Learning Simple Past Tense Using Teams Games Tournaments. Journal of English Language Teaching Innovations and Materials (JELTIM), 2(2), 109-119. DOI: http://dx.doi.org/10.26418/jeltim.v2i2.37832

Journal of English Language Teaching Innovations and Materials (JELTIM), 2(2), 109-119 Copyright @ 2020 by JELTIM, e-ISSN 2657-1617 
In recent years, the Indonesian government has designed the 2013 curriculum as an effort to promote a better quality of the school system. The students are required to learn English grammar with an existing syllabus since English is taught as compulsory subjects. Some obstacles also arise in teaching English grammar to the learners. Many teachers have attempted to make English grammar as a non-threatening, imaginative and beneficial activity in the English curriculum.

According to Wimolmas (2013) as cited in Amjah (2014), less motivated students tend to lose attention, behave poorly, and prompt disciplinary problems in certain learning circumstances. A comparable opinion was also added by Dörnyei \& Ushioda (2013). They stated that sufficient motivation is very important to get excellent language lessons.

Moreover, Westwood (2008, p. 1) affirmed that "teaching methods ." by a set of principles, procedures or strategies must be administered by the teacher to achieve the desired learning condition." Hence, teachers should be able to provide motivation and support to students to improve their interest in learning.

Based on the class observation regarding the factors that affect learning outcomes in Ninth-grade of the Islamic Junior High School in Pontianak, the researchers have found several weaknesses such as 1) fewer students' participation in learning activities; 2) certain students dominate learning activities; 3) grammar is not interesting in the way the teacher presents teaching material because of monotonous methods or techniques; and 4) some students are not interested in learning, feeling bored and disturbing their peers.

Therefore, based on the problems found above, it is imperative to improve the quality of the English grammar learning process. In teaching the simple past tense, teachers should be able to choose appropriate learning techniques so that they can create an active, creative, interesting and exciting atmosphere.

Concerning improving the learners' interest, current classroom action research was conducted to improve the quality of engagement in classroom activities (Ikhsanudin, Sudarsono, \& Salam, 2019). The researchers used magic trick games in the listening class in Pontianak. The action worked quite successfully as the learners seem engaged in the classroom activities through the implementation of the game in combination with the modification of the model of classroom interaction and group discussion.

To solve the problems, the researcher employed the Teams Games Tournaments (TGT) technique with interesting activities to increase the students' interest in learning grammar especially in learning Simple Past Tense. The implementation of the technique encourages the students to learn, become more active, and cooperate with their peer group as if they were in a real situation.

Journal of English Language Teaching Innovations and Materials (JELTIM), 2(2), 109-119 Copyright (C) 2020 by JELTIM, e-ISSN 2657-1617 
The TGT technique carried out to achieve research objectives is cooperative learning. Cooperative learning is suited to be applied as an alternative technique in teaching English as the students worked together in groups with their abilities and learn to share ideas. Bennett $(2005$, p. 5) remarks that "children carry out investigations within small groups in doing various best projects". The technique may help them to develop their ability to work together, communicate, negotiate, and respect others' opinions.

In foreign language learning, 'interest' is not adequately conceptualized. Tin (2016) as cited in Yunita (2018), says that 'interest' is often used to support things rather than personal ones; and can generate search knowledge that leads to the growth of students' knowledge and personalities, survival learning, and life satisfaction. Amjah (2014, p. 189) represents interest as one of the strongest motivations that the students must-have for learning English. Bergin (1999, p. 88) also adds that the term interest can be interpreted as attention, curiosity and involvement.

In a broader perspective, Krapp and Prenzel (2011), as cited in Darlington (2017) point out that the need for students to see activities as meaningful is a supportive factor of interest development which appears in most interest research. Evidence from studies such as Mitchell (1993) showed that students need to understand why a specific activity was important and led to a greater emphasis on the student's involvement in a dialogue regarding lesson objectives and learning outcomes and how these link to the lesson activities.

Stimulating students' interest in the learning process is essential. Interest has a positive effect on students to take classes and activities in class. With good interest, the material could be presented well, and the activities would attract and challenge them to learn.

Some characteristics of a student who is interested in something involves the increase of attention, concentration, pleasant feelings of applied effort, and willingness Krapp (1999, p. 24). Furthermore, Philip (2010, p. 12) concludes in his research that there are four aspects of interest: consciousness, willingness, attention, and pleasure. Each aspect gives a great part of interest building, and the teacher is responsible for making the students have a full interest when learning.

Those characteristics above are talking about the reason why students are interested in the lesson. On the other side, the researchers believe that it is needed to investigate students' bad feelings when they are facing the course as well since that feeling might be observed from their attitudes or behaviors in the class.

As explained by Thornbury (2002, p. 6), "the grammar of a language is a description of how words can change their shape and can be combined into sentences in that language." Furthermore, Xin (2010) states that grammar as a

Journal of English Language Teaching Innovations and Materials (JELTIM), 2(2), 109-119 Copyright @ 2020 by JELTIM, e-ISSN 2657-1617 
basic rule of a particular language has a prominent position in language learning and teaching, although one might argue that it should not be an important part of language assessment. Apte (2004) also explains that teachers will always try to find new, easily understood ways to teach various parts of grammar to students.

To create such a pleasant atmosphere, the researchers planned to apply Team Games Tournament (TGT) Technique in the teaching-learning of simple past tense. As mentioned earlier, it is one of the techniques in the cooperative learning method. Milati (2009:4) stated that “Teams Games Tournament is the way to get the common goal by learning together. Students have to work together to get success and responsible for the success of an individual in their group". So, the purpose is to learn together but the students must be responsible for their group by themselves.

Slavin (1991, p.12) describes that "Teams-Games-Tournaments is one of the cooperative learning models with small groups in the class that consist of 3-5 heterogeneous students in the academic achievement, gender, race or ethnic". On this occasion, TGT is used as an academic tournament in which students compete as representatives of their group with members of other groups who are like them in past academic performance.

The similarity between this study and previous studies is that this game provides the possibility of teaching strategies that can be applied by teachers in grammar teaching, especially Simple Past Tense. Students sometimes feel bored when they are taught with the same methods or techniques in several meetings. Therefore, this technique can give motivation for students to have more enthusiasm for learning English, especially in learning grammar, because they can work in groups with fun and help each other. By using cooperative learning in teams' game tournaments such as TGT, students can interact more between them; they become more active and able to work together in various activities in a relaxed environment.

\section{METHODOLOGY}

In this study, the researcher emphasized the implementation of Teams Games Tournaments (TGT) and their influence on the teaching and learning process, especially increasing student interest in Simple Past Tense. It is essential to describe the method used to conduct research. To find improvement in the teaching-learning process, the researchers tend to use classroom action research (CAR).

According to Marguerite G. Lodico (2010, p. 5), "classroom action research, as the name suggests, is a type of research oriented to impose direct changes in educational settings." Lodico also added that Action Research

Journal of English Language Teaching Innovations and Materials (JELTIM), 2(2), 109-119 Copyright (C 2020 by JELTIM, e-ISSN 2657-1617 
researchers sought to find solutions that could bring immediate change and facilitate improvement in student learning. The research design has the potential to produce a quick change because the teachers are in their work environment when conducting research.

A classroom action research is usually conducted in several cycles. In this classroom action research, one cycle consists of three meetings. In each cycle, the researcher applied TGT activities with materials. If one cycle did not show any improvement, the research activity might be continued in the following cycle until the research obtained any particular improvement. Classroom Action Research was also conducted in three phases: Planning, Acting, Observing and Reflecting.

In the planning phase, the researcher served as the teacher, providing a teaching-learning activity to solve the problem found in the previous teachinglearning process. The researcher formulates some procedures on improving students' interest in learning simple past tense using TGT before coming to the classroom are a complete lesson plan, photograph, observation checklist table, field notes, and interview sheet.

In the acting phase, the teacher worked on the implementation of the overall plan. The researcher tries to apply some techniques or procedures that have been formulated at planning. Two meetings covered one cycle in this research.

Moreover, in the observing phase, the process of the teaching-learning documented by the photographer to get certain details of data to be analyzed. When a researcher who also acts as a teacher is teaching students, collaborators acted as observers to record whatever happens in the teaching-learning process.

Lastly, in the reflecting phase, the researcher reflected on the process, analyzing the first cycle with steps planning, action, and the observation to decide whether to continue the investigation by conducting the next cycle or stop.

Regarding the technique of data analysis, the researcher applied observation and measurement techniques. Observation is a method that aims systematically and selectively to watch and listen to interactions or phenomena that are occurring (Kumar, 2011). The observation technique is the investigation of phenomena where settings occur naturally.

On the other hand, Measurement can be defined as the process by which researchers describe, explain, and predict phenomena and constructs of our daily existence. The importance of measurement in research design cannot be overstated. The measurement aims to identify the percentage of students' interest

Journal of English Language Teaching Innovations and Materials (JELTIM), 2(2), 109-119 Copyright (C) 2020 by JELTIM, e-ISSN 2657-1617 
in learning simple past tense after using the TGT technique. Also, it tries to find out student's achievements in the form of scores to see whether or not an improvement occurs in teaching simple past tense.

Data analysis in this study involved qualitative analysis for primary data and quantitative analysis for secondary data. The qualitative analysis aimed to describe the characteristics of the students, teachers, and also the process of the classroom action research. The analysis illustrated the quality of the participants' behavior in the form of a description of the teaching-learning process based on a list of observations, interviews and field notes to determine the progress of teaching and learning activities, especially student behavior.

On the other hand, the qualitative data from the list of observations and field notes were very important because the data presented the attitude of students during the lesson. Secondary data sources were quantitative data derived from tests. The researcher observed at the level of achievement or increase in the activity of students by comparing the results of the observation list in each cycle.

\section{FINDINGS}

In the implementation of cycle 1 Classroom Action Research, the findings consisted of two parts: the first was for teacher's performance in teachinglearning simple past tense, and the last one was students' behaviour in the learning process. The teacher needed to motivate students in learning for the students more actively and interested. The students still looked afraid of making mistakes in answering the questions. Some students in group discussion were less active, and they were not confident to talk to their friends.

In the interview section of cycle 1, the teacher gave the interview text to each group. However, two of them were taken as representatives of their group to answer the interview given. In the learning simple past tense using TGT, almost all of the groups said that the technique was rather difficult. One of the possible reason was that it was the first time they studied using TGT. Moreover, some of the students said that when learning simple past tense by using TGT, they could understand quite clearly. However, some students stated that there were still difficulties in understanding grammar in using this technique.

On the other hand, the implementation of cycle 2 presented that the students had progressed as they were no longer become fierce or noisy in sharing groups and to communicate with teammates well, even though there was still one group that did. In group discussions, there was still a student who less

Journal of English Language Teaching Innovations and Materials (JELTIM), 2(2), 109-119 Copyright (C) 2020 by JELTIM, e-ISSN 2657-1617 
interested in learning. It could be seen from their test result still which was low. Consequently, the teacher must provide more motivation to the students.

Lastly, cycle 3 of Classroom Action Research was carried out based on the results in cycle 2 . In the teaching and learning process, the teacher has mastered the class. This can be seen from the activities and atmosphere of the students in the class that are already conducive. The use of time in this cycle becomes more effective because the available time is step by step, starting from opening activities, main activities, and closing activities. It has been done based on the time given.

Moreover, the students have shown confidence to discuss in the group. The students have understood to account the score that they got. Besides, the students have intertwined with communicating with other groups. Based on the test, the students' mean score was 91.94. The students' mean score showed that the students, in cycle one, did not pass the standard minimum score, which was 75. The percentage of students who had passed the standard minimum score was $92 \%$. The results of students' score in Simple Past Tense can be seen in figure 1 below:

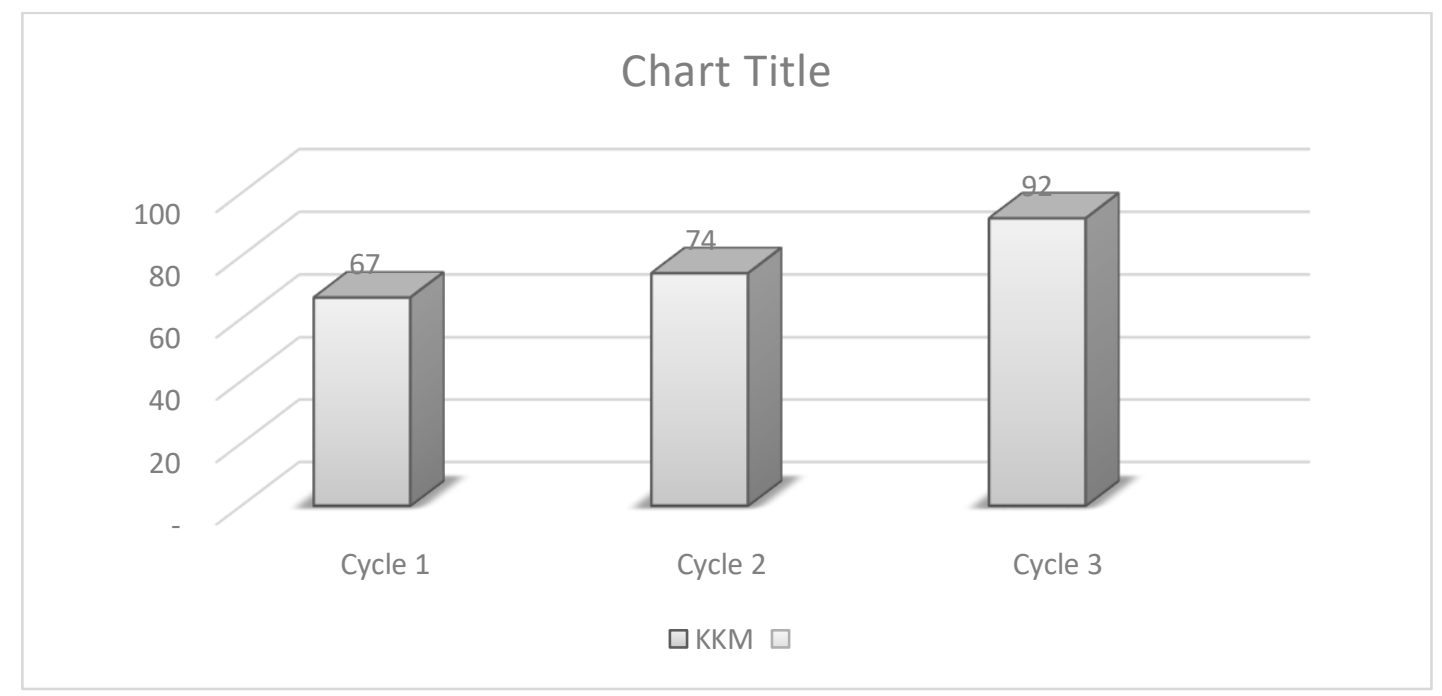

Figure 1. The result of students' score in each cycle

In conclusion, the researchers have answered research problems by describing the teaching-learning process using TGT techniques and test results. Regarding the description of the process in the class, there has been an increase in both student interest and teacher performance when applying the TGT technique. The activities in the class also began to be more active in the second cycle than in the first cycle, and in the third cycle were more fun and interesting.

Journal of English Language Teaching Innovations and Materials (JELTIM), 2(2), 109-119

Copyright (C 2020 by JELTIM, e-ISSN 2657-1617 
Meanwhile, the results of the criteria for student interest in learning also proved to increase after students used the TGT technique. The increase is in the form of a list of observations and their test scores from the first cycle to the third cycle. In other words, simple learning with the TGT technique turned out to be effective in increasing students' interest in learning Simple Past Tense in the ninth grade of MTs Negeri 2 Pontianak.

\section{DISCUSSION}

In conducting this research, the researchers tried to see the extent to which the application of TGT technique can increase students' interest in learning. The data was obtained from the observation checklist, field notes, specification tables, and test results. This technique also encouraged students to be more confident and cooperative in group discussions without shame or hesitation.

The TGT technique proved to be successful in increasing students' interest in this study. This is discussed in the criteria of student interest in the form of simple past tense from the first cycle to the third cycle. The average score from the first cycle presents a percentage of $60 \%$, while for the second cycle, it increases by $82 \%$. Finally, the third cycle is seen to increase by $91 \%$. It shows that students' interest in learning has been fulfilled. The results can be seen in figure 2 below:

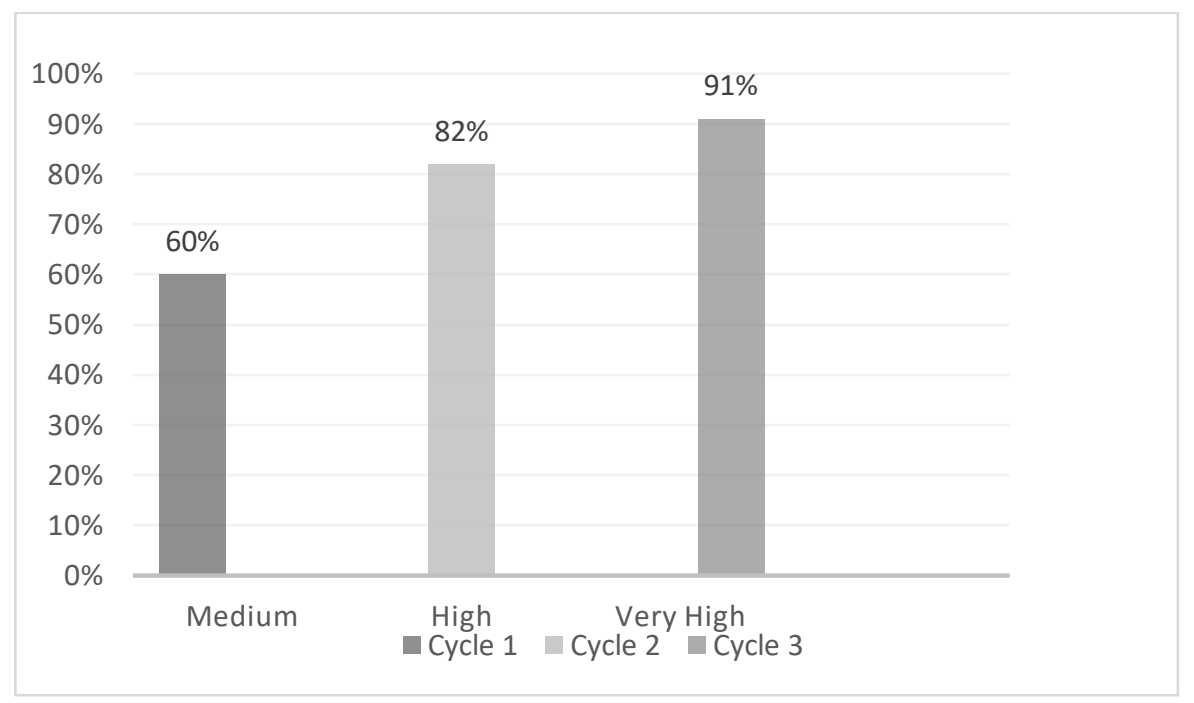

Figure 2 The Percentage of Students' Interest in Learning Using TGT technique

Furthermore, the results of student activities in the classroom look more conducive, fun, and interesting. This can be seen from the results of observation lists for students and student activities during the teaching and learning process as well as descriptions of field notes and teacher performance, the process of teaching and learning and field notes. From the results above, it has been

Journal of English Language Teaching Innovations and Materials (JELTIM), 2(2), 109-119

Copyright (C) 2020 by JELTIM, e-ISSN 2657-1617 
concluded that the TGT technique makes the class fun and increases the learning needs of students who pay much attention to learning.

The use of TGT in teaching simple past tense is proven to increase student achievement in mastering grammar material. Therefore, classroom action research on the use of the TGT technique in teaching simple past tense in MTs Negeri 2 Pontianak is categorized as successful. This success can be achieved because of the teacher's active involvement and approach to students to ask difficult questions in learning.

Furthermore, students' perceptions are another important thing that the research must ask in this study. Group interviews were conducted in focus to collect student perceptions of team game tournaments. In focus group interviews, students stated that they benefited greatly from learning from the application of the TGT technique. From students 'answers to the questions given, it was concluded that students' perceptions of the application of the TGT technique, according to their critical ideas, students assumed that this technique made them easy to understand in grammar learning

In conclusion, it could be determined that this research was satisfactory. Using the TGT technique, the students can interact and take part in group discussions freely without shy or doubt to share their ideas. This technique allowed the students to engage in their group and also gave the students a motivation to compete. Finally, students' perceptions of the implementation of a team game tournament (TGT) are positive and remarkably good.

\section{CONCLUSION}

It is concluded that the TGT technique can be employed to increase students' interest in learning, which has been carried out in three cycles. By using this technique in class, students were proven to be more active and encouraged in learning. This has an impact on increasing their interest in learning and mastery of their grammar, especially in the form of simple past tense. From teacher and student observations, field notes and interviews, it was shown that the teaching-learning process has improved significantly. This concludes that classroom action research is not only used to increase students' interest in learning grammar mastery, but also helped teachers to practice reflective and to improve the quality of teaching.

There are some suggestions that the researcher would like to offer as follows. The first one, the teacher's role in managing the class in apply TGT is also important to make the learning activity more effective and efficient in order to make the subject easy to be understood by the students. Secondly, Teachers

Journal of English Language Teaching Innovations and Materials (JELTIM), 2(2), 109-119 Copyright (C) 2020 by JELTIM, e-ISSN 2657-1617 
should teach grammar by using real objects of teaching and learning in the classroom, so the students will be interested in learning grammar.

The suggestions for students are that they should learn more about English grammar so that they can gain understanding and more knowledge. It would be better for them to practice more about grammar. Moreover, the students should show their confidence by not feeling afraid when the teacher asks them to do the practice.

Lastly, the researcher hopes that the result of this research can be used as a reference for other researchers who conduct the same research interest.

\section{REFERENCES}

Apte, D. (2004). Teaching The Past Tense Verbs: A New Approach To Teaching Verb. ABC Journal 15-19, 1.

Amjah, D. Y. (2014, April ). A Study of Teachers' Strategies so Develop Students' Interest towards Learning English as a Second Language. Procedia-Social and Behavioral Science, 188-192.

Bennett, Neville. 2005. Teaching through play teachers thinking and classroom practice. USA: Open University press

Creswell, J.W. 2003. Research design: qualitative, quantitative, and mixed method approaches. Thousand Oaks, California: Sage Publications, Inc.

Dörnyei, Z., \& Ushioda, E. (2013). Teaching and researching motivation, second edition. In Teaching and Researching Motivation, Second Edition. https://doi.org/10.4324/9781315833750

Ikhsanudin, I., Sudarsono, S., \& Salam, U. (2019). Using Magic Trick ProblemBased Activities to Engage FKIP UNTAN Students: A Classroom Action Research in Listening for General Communication Class. JELTIM, 1(1), 715.

Retrieved from http://jurnal.untan.ac.id/index.php/JELTIM/article/view/31620.

Krapp, A. 2002. Structural and dynamic aspects of interest development: theoretical considerations from an ontogenetic perspective. Learning and Instruction, 12(4), 383409.

Lodico, G, Marguerite, Dean T. Spaulding, Katherine H. Voegtle. 2006. Methods in Educational Research From Theory to Practice. San Fransisco. Jossey.

Journal of English Language Teaching Innovations and Materials (JELTIM), 2(2), 109-119

Copyright (C 2020 by JELTIM, e-ISSN 2657-1617 
Milati, Nuril. 2009. Penerapan Pembelajaran Kooperatif Tipe TGT (Teams Game Tournament) Untuk Meningkatkan Prestasi Belajar Siswa. Skripsi. Malang. UIN Maulana Malik Ibrahim. http://www.clt.astate.edu/gme eks/3033/PPT/CooperativeLea rning.ppt.

Mitchell, S. 1993. Problem-based learning: A review of literature on its outcomes and implementation issues. Academic Medicine, 68, 52-81.

Slavin, Robert E. 1991. Educational Psychology: Theory into Practice 3. JohnsHopkins University: Allyn and Bacon.

Thornbury, Scott . 2002. How to Teach Vocabulary. Harlow: Pearson Education

Westwood, P. 2008. What Teachers Need to Know about Teaching Methods. Victoria, Acer Press Australia.

Wimolmas, R. 2013. A survey study of motivation in English language learning of first year undergraduate students at Sirindhorn International Institute. Bangkok, Thailand.

Yunita, R. 2018. Investigating Interest Development of Indonesian Students in an MA TEFL Programme in Learning English as an L2. Conference Paper. The University of Birmingham

\section{Authors' Brief CV}

Yusnita holds a Master's degree in English Education from Universitas Tanjungpura Pontianak, West Kalimantan, Indonesia. Currently, she is an English teacher of Madrasah Tsanawiyah Negeri 2 Pontianak.

Yuniarti got her Master's degree from Universitas Tanjungpura Pontianak. Presently. She works as the Head of Language Center of Universitas Muhammadiyah Pontianak and an English lecturer at the Faculty of Teacher Training and Education of the university. She also teaches test preparation classes. She is particularly interested in developing ESP materials for EFL, and translation.

Journal of English Language Teaching Innovations and Materials (JELTIM), 2(2), 109-119

Copyright (C 2020 by JELTIM, e-ISSN 2657-1617 